BIOMEDICAL AND BIOSOCIAL ANTHROPOLOGY
Official Journal of the International Academy
of Integrative Anthropology
journal homepage: http://bba-journal.com

\title{
Modern aspects of social protection of combatants depending on the severity of disability
}

Bieliaieva N. M., Yavorovenko O. B., Kurylenko I. V., Prysiazhniuk L. V., Dziuniak O. V., Proskurina O. F., Yavorovenko M. $F$.

Research Institute for Rehabilitation of Persons with Disabilities of National Pirogov Memorial Medical University, Vinnytsya, Ukraine

\section{ARTICLE INFO}

Received: 17 June, 2019

Accepted: 22 July, 2019

UDC: $(616-036.86+364.013)$ :

$355.292 .3(477)$

\section{CORRESPONDING AUTHOR}

e-mail: ndiri-info@ukr.net Yavorovenko O. B.
The urgency of the problem is due to the significant increase in recent years in the number of young and middle-aged people who have passed the war, the need to develop adequate measures of social assistance and protection. An important task in the organization of the rehabilitation process is to determine the structure of the needs of servicemen with disabilities in various types of medical and social care and the development of individual rehabilitation programs (IRP) based on them. The purpose of the study: to determine the structure of the needs of servicemen with disabilities in medical and social rehabilitation depending on the severity of disability. Statistical data from 25 administrative territories of Ukraine for 2018 are analyzed, the needs of participants of military service with disabilities in medical and social rehabilitation measures, their structure are calculated. The data of the information base of the centers and the bureau of medical and social examination of the regions were used. Processing of the primary material was performed using the universal statistical package "Excel". In 2018, medical and social expert commissions (MSEC) of Ukraine for the first time and re-certified and recognized persons with disabilities 7843 combatants. Of these, disability of group I (IA and IB) was established in $2.6 \%$, II - in $29.2 \%$, III - in $68.2 \%$ of cases. All victims for MSEC were formed IRP. The dependence of the needs of combatants in medical and social rehabilitation measures on the severity of disability has been established. For persons with disabilities of groups II and III, priority is given to medical and professional rehabilitation, group I - social rehabilitation and technical means of rehabilitation with medical support. Of the medical rehabilitation services for persons with II and III groups of disability, sanatorium treatment is significant, and group I - rehabilitation therapy. Among vocational rehabilitation services, employment in production conditions is important - for persons with group III disabilities, in specially created conditions - for persons with group II disabilities, at home - for persons with group I disabilities. Vocational training was offered to a small number of people with disabilities of all groups. Among social rehabilitation services and technical means of rehabilitation, the services of social workers of territorial social service centers were significant for representatives of all disability groups, simpler means of transportation for persons of group III disability and more complex means for persons of group I. Determining the characteristics of the needs of servicemen with disabilities depending on its severity allows MSEC specialists to better form the IRP, develop targeted rehabilitation programs at the regional level, assess shortcomings in the organization of the rehabilitation process and build a rehabilitation system for combatants. Keywords: social protection, disability, combatants, rehabilitation.

\section{Introduction}

The use of military force in armed struggle is accompanied by casualties and an increase in the number of casualties among servicemen and special services [3]. Therefore, in the total number of persons with disabilities, a special group consists of persons with disabilities due to injury, contusion or mutilation received in the performance of military service [10]. Thus, in the United States in 2012 there were 2.73 million people with disabilities due to 
hostilities (combatants) and military service [11]; in the Russian Federation - more than 120 thousand people [12].

According to the General Staff of the Armed Forces of Ukraine (AFU), since the beginning of the anti-terrorist operation (ATO) in eastern Ukraine, the format of which was changed in April 2018 to Operation United Forces (OUF), as of March 2019, 9,423 servicemen of AFU were wounded. [9].

Social protection of persons with disabilities who participated in the ATO/OUF is one of the priorities of the state and society $[1,13,15,16,18]$. The urgency of the problem is due to the significant increase in recent years in the number of young and middle-aged people who have passed the war, as well as the need to develop adequate measures of social assistance and protection. These individuals are in dire need of state guarantees in obtaining employment, housing, education, medical care, social assistance, spiritual development, including rehabilitation. According to experts, up to $80 \%$ of combat victims are shown rehabilitation measures $[6,7,19]$.

An important task in the organization of the rehabilitation process is to determine the structure of the needs of servicemen with disabilities in various types of medical and social care and develop individual rehabilitation programs (IRP) based on them, the main function of which is comprehensive rehabilitation of victims $[4,5,17]$. It is aimed at the end result - improving the functioning of the sick person, overcoming the limitations of life, achieving social independence [14].

The purpose of the study: to determine the structure of the needs of servicemen with disabilities in medical and social rehabilitation depending on the severity of disability.

\section{Materials and methods}

The analysis of statistical data from 25 administrative territories of Ukraine for 2018 is carried out, the needs of participants of military service with disability in measures of medical and social rehabilitation, the structure of these needs are calculated. The data of the information base of the centers and bureaus of medical and social examination of oblasts are used - annual statistical reporting forms (form № 14 - Report on the causes of disability, indications for medical, professional and social rehabilitation; order of the Ministry of Health of Ukraine dated 10.07.2007, № 378).

Research methods: statistical, analytical, method of expert assessments. Processing of the primary material was performed using the universal statistical package "Excel". The difference at $p<0.05$ was considered significant.

\section{Results}

In 2018, medical and social expert commissions (MSEC) of Ukraine for the first time and re-certified and recognized persons with disabilities 7843 combatants in the database. Of these, disability of group I (IA and IB) was established in $2.6 \%$, II - in $29.2 \%$, III - in $68.2 \%$ of cases.
All victims during MSEC were formed IRP. The total number of medical and social rehabilitation measures was 21952 or 2.8 measures per victim, regardless of the severity of the disability.

In the general structure of needs of servicemen in measures of medical and social rehabilitation, medical rehabilitation services make up $64.1 \%$, professional - 2 $5.5 \%$, social - $10.4 \%$.

Medical rehabilitation is the main type of rehabilitation process. In the structure of needs of combatants with disabilities of the I group, it amounted to $52.9 \%$, of the II group $-62.5 \%$, of the III group - $65.2 \%$.

Among the medical rehabilitation services for people of all disability groups, the most important were rehabilitation therapy and sanatorium treatment; reconstructive surgery and orthoses are in demand in isolated cases (Table 1). Persons with group I disability were significantly more often in need of rehabilitation therapy than patients with group II and III $(p<0.05)$, and with group II and III - spa treatment $(p<0.05)$, which is associated with the severity of the general condition patients, and with the presence of indications and contraindications to stay in sanatoriums.

Vocational rehabilitation included vocational training and employment services.

The issue of professional training and retraining of servicemen with disabilities is very important. Retraining of servicemen with disabilities should be carried out considering the state of their health, individual characteristics, consistency of professional development before and after discharge from military service, based on good knowledge of labor market needs in specialists of various fields, be focused on fundamentally new areas of activity (business and other modern professions that appear in the labor market) and provide employment for those who have been trained.

In the structure of needs of persons with disabilities of group I, vocational training amounted to $0.4 \%$, group II $0.6 \%$, group III - $2.1 \%$ (Table 2 ).

Vocational training and retraining were offered in the conditions of production and in higher educational institutions of I-IV levels to combatants of II-III groups, only in higher educational institutions of I-IV levels - I groups without statistically significant differences in groups (see Table 2).

Employment services based on the structure of needs of persons of group I accounted for $4.2 \%$, group II for $22.3 \%$, and group III for $25.3 \%$. For persons of group I employment in domestic $(p<0.001)$, group II - in specially created conditions $(p<0.001)$, group III - in normal conditions of production $(p<0.001)$ was relevant (see Table 2). Combatants with disabilities who underwent vocational rehabilitation and were employed in group II disability accounted for $18.9 \%$, in group III - $81.1 \%$. The number of servicemen who want to work and are registered with the social security bodies is $27.1 \%$, of persons with disabilities of group I - $3.5 \%$, group II - $23.8 \%$, group III - $29.4 \%$ with a significant predominance 
Bieliaieva N. M., Yavorovenko O. B., Kurylenko I. V., Prysiazhniuk L. V., Dziuniak O. V., Proskurina O. F., Yavorovenko M. F.

Table 1. Structure of needs in measures of medical rehabilitation of participants of hostilities with disability depending on disability group.

\begin{tabular}{|c|c|c|c|c|c|c|c|}
\hline \multirow{2}{*}{ Services } & \multirow{2}{*}{ Total $\mathrm{n}=14070$} & \multicolumn{3}{|c|}{ Disability group } & $\mathrm{P}_{1}$ & $\mathrm{p}_{2}$ & $\mathrm{P}_{3}$ \\
\cline { 3 - 8 } & & $\begin{array}{c}\mathrm{I} \\
\mathrm{n}=299\end{array}$ & $\begin{array}{c}\mathrm{II} \\
\mathrm{n}=4061\end{array}$ & $\begin{array}{c}\mathrm{III} \\
\mathrm{n}=9710\end{array}$ & I-II & II-III & I-III \\
\hline Rehabilitation therapy & $7644(54.3 \%)$ & $182(60.9 \%)$ & $2216(54.6 \%)$ & $5246(54.1 \%)$ & $<0.05$ & $<0.1$ & $<0.05$ \\
\hline Reconstructive surgery & $100(0.7 \%)$ & $6(2.0 \%)$ & $45(1.1 \%)$ & $49(0.5 \%)$ & $<0.1$ & $<0.1$ & $<0.1$ \\
\hline Prosthesis & $99(0.7 \%)$ & $13(4.3 \%)$ & $33(0.8 \%)$ & $53(0.5 \%)$ & $<0.1$ & $<0.1$ & $<0.1$ \\
\hline Spa treatment & $6227(44.3 \%)$ & $98(32.8 \%)$ & $1767(43.5 \%)$ & $4362(44.9 \%)$ & $<0.05$ & $<0.1$ & $<0.001$ \\
\hline
\end{tabular}

Table 2. The structure of needs for measures of professional rehabilitation of combatants with disabilities depending on the disability group.

\begin{tabular}{|l|c|c|c|c|c|c|c|}
\hline \multirow{2}{*}{ Services } & \multirow{2}{*}{ Total } & \multicolumn{3}{|c|}{ Disability group } & $\mathrm{p}_{1}$ & $\mathrm{P}_{2}$ & $\mathrm{P}_{3}$ \\
\cline { 3 - 7 } & & $\mathrm{I}$ & $\mathrm{II}$ & $\mathrm{III}$ & $\mathrm{I}-\mathrm{II}$ & $\mathrm{II}-\mathrm{III}$ & $\mathrm{I}-\mathrm{III}$ \\
\hline Professional education: & $\mathrm{n}=359$ & $\mathrm{n}=2$ & $\mathrm{n}=39$ & $\mathrm{n}=318$ & & & \\
\hline - in terms of production & $206(57.4 \%)$ & - & $23(59.0 \%)$ & $183(57.5 \%)$ & & $<0.1$ & \\
\hline - in special educational institutions & $6(1.7 \%)$ & - & $1(2.6 \%)$ & $5(1.6 \%)$ & & $<0.1$ & \\
\hline - in higher educational institutions of I-IV levels & $147(40.9 \%)$ & $2(100 \%)$ & $15(38.4 \%)$ & $130(40.8 \%)$ & $<0.1$ & $<0.1$ & $<0.1$ \\
\hline Employment: & $\mathrm{n}=5240$ & $\mathrm{n}=24$ & $\mathrm{n}=1451$ & $\mathrm{n}=3765$ & & & \\
\hline - in terms of production & $4390(83.8 \%)$ & $6(25.0 \%)$ & $702(48.4 \%)$ & $3682(97.8 \%)$ & $<0.1$ & $<0.001$ & $<0.001$ \\
\hline - in specially created conditions & $777(14.8 \%)$ & $7(29.8 \%)$ & $687(47.3 \%)$ & $83(2.2 \%)$ & $<0.1$ & $<0.001$ & $<0.1$ \\
\hline - at home & $73(1.4 \%)$ & $11(45.8 \%)$ & $62(4.3 \%)$ & - & $<0.001$ & & \\
\hline
\end{tabular}

Table 3. The structure of needs for measures of social rehabilitation of participants in hostilities with disabilities, depending on the disability group.

\begin{tabular}{|c|c|c|c|c|c|c|c|}
\hline \multirow[b]{2}{*}{ Services } & \multirow{2}{*}{$\begin{array}{c}\text { Total } \\
\mathrm{n}=2283\end{array}$} & \multicolumn{3}{|c|}{ Disability group } & \multirow{2}{*}{$\frac{p_{1}}{|-| \mid}$} & \multirow{2}{*}{$\frac{\mathrm{p}_{2}}{\|I-I\|}$} & \multirow{2}{*}{$\frac{\mathrm{p}_{3}}{|-|||}$} \\
\hline & & $\begin{array}{c}1 \\
n=240\end{array}$ & $\begin{array}{c}\mathrm{II} \\
\mathrm{n}=947\end{array}$ & $\begin{array}{c}\mathrm{III} \\
\mathrm{n}=1096\end{array}$ & & & \\
\hline $\begin{array}{l}\text { Adaptation of housing for the needs of people } \\
\text { with disabilities }\end{array}$ & $40(1.8 \%)$ & $25(10.4 \%)$ & $15(1.6 \%)$ & - & $<0.1$ & & \\
\hline Services of territorial centers of social service & $880(38.5 \%)$ & $50(20.8 \%)$ & $423(44.7 \%)$ & $407(37.1 \%)$ & $<0.001$ & $<0.001$ & $<0.001$ \\
\hline Means for walking & $667(29.2 \%)$ & $56(23.4 \%)$ & $239(25.2 \%)$ & $372(34.0 \%)$ & $<0.1$ & $<0.001$ & $<0.05$ \\
\hline Prosthetic and orthopedic products & $516(22.6 \%)$ & $38(15.8 \%)$ & $209(22.1 \%)$ & $269(24.5 \%)$ & $<0.1$ & $<0.1$ & $<0.1$ \\
\hline Sign language technology & $40(1.7 \%)$ & - & $9(1.0 \%)$ & $31(2.8 \%)$ & & $<0.1$ & \\
\hline Typhlotechnics & $6(0.3 \%)$ & $1(0.4 \%)$ & $1(0.1 \%)$ & $4(0.4 \%)$ & $<0.1$ & $<0.1$ & $<0.1$ \\
\hline Means of communication & $2(0.1 \%)$ & - & - & $2(0.2 \%)$ & & & \\
\hline Wheelchairs & 85 (3.7 \%) & $56(23.4 \%)$ & $22(2.3 \%)$ & $7(0.6 \%)$ & $<0.001$ & $<0.1$ & $<0.001$ \\
\hline Indications for motor vehicles & $47(2.1 \%)$ & $14(5.8 \%)$ & $29(3.0 \%)$ & $4(0.4 \%)$ & $<0.1$ & $<0.1$ & $<0.1$ \\
\hline
\end{tabular}

of those wishing to group III disability $(p<0.05)$.

In the structure of needs, social rehabilitation measures for group I combatants amounted to $42.5 \%$, group II - $14.5 \%$, group III - $7.4 \%$.

The most popular among all groups of disabilities were technical aids that facilitate mobility, prosthetic and orthopedic products and services of social workers of territorial centers, who help in self-care, household issues. However, each group of disabilities has features (Table 3). Thus, for persons with disabilities of the first group additional means for walking, wheelchairs, services of social workers, prosthetic and orthopedic products, adaptation of housing for own needs were needed; for persons with disabilities of the II and III groups - services of social workers, technical means for movement, prosthetic and orthopedic products. Statistically significant indicators were found for the first group of disability - the provision of wheelchairs $(p<0.001)$, the second group - the services of social workers of territorial centers $(p<0.001)$, the third group - the provision of additional means of transportation $(p<0.05)$.

\section{Discussion}

The needs of people with disabilities, including servicemen, in medical and social rehabilitation measures form a system of rehabilitation in the state. At present, 
Ukraine has a mixed system of rehabilitation, mainly a decentralized form with the opening of mostly professional and social rehabilitation centers of the Ministry of Social Policy. In the structure of the system of medical and social rehabilitation of ATO/OUF participants with disabilities, the main place in providing medical, vocational, psychological, social rehabilitation, provision of technical means and medical devices is given to civilian institutions. The corresponding role is played by public organizations that provide psychological, labor, physical culture, sports, social and domestic rehabilitation.

The Concept of the State Target Program was approved by the Order of the CMU of 12.07.2017 № 475-r, and on 5.12.2018 the Resolution of the CMU "On approval of the State Target Program on physical, medical, psychological rehabilitation and social and professional readaptation of ATO participants and persons involved in the implementation of measures to ensure national security and defense, repulse and deter the armed aggression of the Russian Federation in Donetsk and Luhansk regions, ensuring their implementation for the period up to 2020". Its adoption will help ensure the implementation of measures for rehabilitation and readaptation of combatants, aimed at administering their needs, raising their awareness of participation in the relevant processes of readaptation to civilian life, strengthening their social protection, maintaining proper moral and psychological condition, addressing urgent issues. medical, psychological, physical, professional, physical culture and sports, social rehabilitation and readaptation, as well as to increase the effectiveness of interaction between central and local executive bodies, local governments, public and international organizations on these issues.

The procedure for providing sanatorium treatment to combatants and persons with disabilities as a result of the war from among ATO participants is regulated by the CMU Resolution of 31.03.2015 № 200 "On approval of the Procedure for using funds provided in the state budget to provide injured ATO participants with sanatorium treatment" (with changes). And by the resolution of the CMU of 01.03.2017 № 110 the authority to purchase vouchers was delegated to the places, and the participants of the ATO/ OUF were given the opportunity to choose a sanatorium for rehabilitation. The existing system of procurement of sanatorium-resort services has been changed to reimburse the cost of sanatorium-resort treatment services (vouchers) for persons with disabilities and injured participants of ATO/OUF due to non-cash transfer of funds to sanatorium-resort establishments for services provided on the basis of a tripartite agreement (person management - sanatorium) and determined by the managers of funds provided for these purposes, lowerlevel regional and district bodies of social protection.

The procedure for organizing social and professional adaptation of ATO participants, approved by the Resolution of the CMU of 21.06.2017 № 432, provides for: creation of an effective mechanism for restoring professional skills of ATO/OUF participants as an integral part of their adaptation to civilian life, ensuring their rights to education life, increasing the efficiency of solving problematic issues of database participants related to civilian professional activities, strengthening their competitiveness in the labor market.

According to the research data, in practice there are modest results of work with servicemen with disabilities in vocational training and employment, due to medical, demographic, socio-psychological characteristics of servicemen with disabilities, their lack of awareness, rent settings, difficult socio-economic conditions. which determines the need for an integrated approach to their solution, targeted planning and funding, coordination of efforts between participants in the rehabilitation process.

In connection with this order of the CMU "On approval of the action plan for the implementation of the Concept of the state system of vocational guidance of the population" from 4.07.2018 provides for the creation of conditions for intensifying work on vocational guidance, including professional reorientation and adaptation of servicemen who are discharged or discharged from military service, participants in hostilities.

The dependence of the needs of database participants in medical and social rehabilitation measures on the severity of disability has been established. For persons with disabilities of groups II and III, priority is given to medical and professional rehabilitation, group I - social rehabilitation and technical means of rehabilitation with medical support. Of the medical rehabilitation services for persons with II and III groups of disability, sanatorium treatment is significant, and group I - rehabilitation therapy. Among vocational rehabilitation services, employment in production conditions is important - for persons with group III disabilities, in specially created conditions - for persons with group II disabilities, at home - for persons with group I disabilities. Vocational training as an effective mechanism for professional adaptation, acquisition of a profession, retraining, socialization was offered to a small number of people with disabilities of all groups. According to other studies, the growing number of people with disabilities of group III requires the preparation of IRP, which would, in addition to physical and medical, also include vocational and occupational rehabilitation [2].

Social rehabilitation involves providing conditions for social adaptation of a person with a disability, independent social functioning in the family and society through the consistent use of functionality [8]. Among social rehabilitation services and technical means of rehabilitation, the services of social workers of territorial social service centers were significant for representatives of all disability groups, simpler means of transportation for persons of group III disability and more complex means for persons of group I. 


\section{Conclusions}

Determining the characteristics of the needs of servicemen with disabilities depending on its severity allows MSEC specialists to better form the IRP, develop

\section{References}

[1] About the procedure of providing participants of the antiterrorist operation with technical and other means of rehabilitation (2015). Medical law, (1), 78-82.

[2] Havlovsky, O. D., Holovanova, I. A., Khorosh, M. V., \& Tovstyak, M. M. (2019). The importance of research into the dynamics of disability in Ukraine among war participants to determine the scope of care and rehabilitation. Clinical and Preventive Medicine, 3-4(9-10), 22-30. doi: 10.31612/26164868.3(9).2019.03

[3] Institute of Medicine (2013). Returning Home from Iraq and Afghanistan: Assessment of Readjustment Needs of Veterans, Service Members, and Their Families. Washington, DC: The National Academies Press. doi: 10.17226/13499

[4] Ipatov, A. V., \& Korobkin, Yu. I. (2014). Features of medical and social examination in the combat participants expertise. Ukrainian Bulletin of Medical and Social Expertise, 4(14), 412.

[5] Kasynets, S. S., Holovanova, I. A., Palamarchuk, D. V., \& Kravtsiv, I. S. (2018). The main directions of rehabilitation of participants of hostilities in Poltava region. Chronicle of traumatology and orthopedics, (1-2), 49-52.

[6] Korchagina, E. V. (2008). The consequences of fighting traumatic brain injury and limitation of life in former soldiers of working age in modern conditions. (PhD thesis). https:// www.dissercat.com/content/posledstviya-boevoi-cherepnomozgovoi-travmy-i-ogranichenie-zhiznedeyatelnosti-ubyvshikh-vo

[7] Leskiv, B. B., \& Shevchenko, S. I. (2016). Two year experience of treatment and medical rehabilitation of participants of antiterror operation in medical and preventive establishments of general network of Zhytomyr area. Ukraine. Nation's Health, 4(1), 58-62.

[8] Matiash, M. M., Dykun, O. P., Matiash, O. M., \& Hrynenko, Yu. A. (2017). Rehabilitation of the disabled persons who are combatants, in the Kyiv region. International Neurological Journal, 4(90), 23-34. doi: 10.22141/22240713.4.90.2017.107258

[9] Official response of the Head of the Personnel Center of the Armed Forces of Ukraine Y. Voronin to Tuco Ramirez's request. (2019). URL: https://dostup.pravda.com.ua/request/47518/ response/112005/attach/3/273\%2025.03.2019.doc. 28.03.2019. targeted rehabilitation programs at the regional level, assess shortcomings in the organization of the rehabilitation process and build a rehabilitation system for combatants.

[10] Oster, C., Morello, A., Venning, A., Redpath, P., \& Lawn, S. (2017). The health and wellbeing needs of veterans: a rapid review. BMC Psychiatry, 17(1), 414. doi: 10.1186/s12888017-1547-0

[11] Persons with a disability: barriers to employment, types of assistance, and other labor-related issues: Department of Labor USA: News Release. USDL-13-0729. 2013, April. 20 pp. URL: https://www.bls.gov/news.release/pdf/dissup.pdf

[12] Sajfullin, V. G. (2011). Management of the social rehabilitation of disabled combat operations in the Russian Federation: sociological analysis. (PhD thesis). https:// www.dissercat.com/content/upravlenie-sotsialnoireabilitatsiei-invalidov-boevykh-deistvii-v-rossiiskoi-federatsii

[13] Sharshatkin, D. Yu. (2016). The concept of improving the provision of administrative and social services to participants in the anti-terrorist operation. Law and public administration, (4), 153-157.

[14] Shevchuk, V. I., Beliaieva, N. M., Yavorovenko, O. B., \& Kurylenko, I. V. (2018). The needs of people with disabilities - participants in the anti-terrorist operation in medical and social rehabilitation: A guide. Vinnytsia: FOP Rogalska I. O. ISBN 978-617-7556-39-7

[15] Sysoienko, I. V. (2015). Legal and regulatory support for the rehabilitation of victims of the anti-terrorist operation. Medical Rehabilitation, Balneology and Physiotherapy, 2(82), 5-10.

[16] Vetlynskyi, S. O. (2016). Social protection of military men under conditions of the anti-terrorist operation. Efficiency of public administration, (4), 198-205.

[17] Volianskyi, O. M., \& Kikh, A. Yu. (2015). The form of the individual program of rehabilitation of the servicemen wounded during anti-terrorist operation in the period of receiving by them the status "VA disability". Medical Hydrology And Rehabilitation, 13(4), 59-60.

[18] Vorona, P. V. (2018). Ways of social rehabilitation of participants of Ukrainian-Russian war in the east of Ukraine: international experience. Bulletin of the National Academy of Public Administration under the President of Ukraine. Series: Public Administration, (3), 55-62. doi: 10.5281/ZENODO.1240793

[19] Yena, A. I., Maslyuk, V. V., \& Sergienko, A. V. (2014). Relevance and organizational principles of medical and psychological rehabilitation of the counterterrorist operation. Scientific Journal of the Ministry of Health of Ukraine, 1(5), 5-16.

\section{СУЧАСНІ АСПЕКТИ СОЦІАЛЬНОГО ЗАХИСТУ УЧАСНИКІВ БОЙОВИХ ДІЙ В ЗАЛЕЖНОСТІ ВІД ВАЖКОСТІ ІНВАЛІДНОСТІ}

Беляєва Н. М., Яворовенко О. Б., Куриленко І. В., Присяжнюк Л. В., Дзюняк О. В., Проскуріна О. Ф., Яворовенко М. Ф. Актуальність проблеми обумовлена значним збільшенням за останні роки чисельності осіб молодого та середнього працездатного віку, які пройшли війну, необхідністю розробки адекватних заходів соціальної допомоги та захисту. В організації реабілітаційного процесу важливим завданням є визначення структури потреб військовослужбовців з інвалідністю в різних видах медико-соціальної допомоги та розробка на їх основі індивідуальних програм реабілітації (ІПР). Мета дослідження: визначення структури потреб військовослужбовців з інвалідністю в медико-соціальній реабілітації в залежності від важкості інвалідності. Проаналізовані статистичні дані з 25 адміністративних територій України за 2018 рік, розраховані потреби учасників військової служби з інвалідністю в заходах медико-соціальної реабілітації, їх структура. Використані дані інформаційної бази центрів та бюро медико-соціальної експертизи областей. Обробку первинного матеріалу проводили з використанням універсального статистичного пакету "Ехсеl". У 2018 році медико-соціальними експертними комісіями (МСЕК) України вперше та повторно освідчено та визнано особами з інвалідністю 7843 учасника бойових дій. 3 них інвалідність I (IA та ІБ) групи встановлена в 2,6 \%, II - в 29,2 \%, III - в 68,2 \% випадків. Усім постраждалим на МСЕК були сформовані ІПР. Встановлена залежність потреб учасників бойових дій в заходах медико-соціальної реабілітації від важкості інвалідності. 
Для осіб з інвалідністю II та III групи пріоритетними є медична та професійна реабілітація, I групи - соціальна реабілітація та технічні засоби реабілітації при медичному супроводі. 3 послуг медичної реабілітації для осіб з II та III групою інвалідності суттєвим є санаторно-курортне лікування, І групою - відновна терапія. 3 послуг профресійної реабілітації важливим є працевлаштування в умовах виробництва - для осіб з інвалідністю III групи, в спеціально створених умовах - для осіб з інвалідністю // групи, в домашніх умовах - для осіб з інвалідністю I групи. Професійне навчання пропонувалось невеликій кількості осіб з інвалідністю усіх груп. 3 послуг соціальної реабілітації та технічних засобів реабілітації суттєвими були послуги соціальних працівників територіальних центрів соціального обслуговування для представників усіх груп інвалідності, більш прості засоби для пересування - для осіб III групи інвалідності та більш складні - для осіб I групи. Визначення особливостей потреб військовослужбовців з інвалідністю в залежності від ї̈ важкості дозволяє спеціалістам МСЕК більш якісно формувати ІПР, розробляти цільові програми реабілітації на регіональному рівні, оцінювати недоліки в організації реабілітаційного процесу та побудові системи реабілітації учасників бойових дій.

Ключові слова: соціальний захист, інвалідність, учасники бойових дій, реабілітація.

\section{СОВРЕМЕННЫЕ АСПЕКТЫ СОЦИАЛЬНОЙ ЗАЩИТЫ УЧАСТНИКОВ БОЕВЫХ ДЕЙСТВИЙ В ЗАВИСИМОСТИ ОТ ТЯЖЕСТИ ИНВАЛИДНОСТИ}

Беляева Н. Н., Яворовенко О. Б., Куриленко И. В., Присяжнюк Л. В., Дзюняк Е. В., Проскурина О. Ф., Яворовенко Н. Ф. Актуальность проблемы обусловлена значительным увеличением за последние годы численности лиц молодого и среднего трудоспособного возраста, которые прошли войну, необходимостью разработки адекватных мероприятий социальной помощи и защиты. В организации реабилитационного процесса важным заданием является определение структуры потребностей военнослужащих с инвалидностью в различных видах медико-социальной помощи и разработка на их основе индивидуальных программ реабилитации (ИПР). Цель исследования: определение структуры потребностей военнослужащих с инвалидностью в медико-социальной реабилитации в зависимости от тяжести инвалидности. Проведен анализ статистических данных из 25 административных территорий Украины за 2018 год, рассчитана потребность участников военной службы с инвалидностью в мероприятиях медико-социальной реабилитации, их структура. Использованы данные информационной базы центров и бюро медико-социальной экспертизы областей. Обработка первичного материала проведена с использованием универсального статистического пакета "Excel". В 2018 году медико-социальными экспертными комиссиями (МСЭК) Украины впервые и повторно освидетельствована и определена инвалидность 7843 участникам боевых действий. Из них инвалидность I (IA и ІБ) группы установлена в 2,6 \%, II - в 29,2 \%, III - в 68,2 \% случаев. Всем пострадавшим на МСЭК были сфрормированы ИПР. Установлена зависимость потребностей участников боевых действий в мероприятиях медико-социальной реабилитации от тяжести инвалидности. Для лиц с инвалидностью II и III группы приоритетными являются медицинская и профессиональная реабилитация, $I$ группы - социальная реабилитация и технические средства реабилитации при медицинском сопровождении. Из услуг медицинской реабилитации для лиц с II и III группой инвалидности существенным является санаторно-курортное лечение, с I группой - восстановительная терапия. Из услуг профессиональной реабилитации имеет значение трудоустройство в условиях производства - для лиц с инвалидностью III группы, в специально созданных условиях - для лиц с инвалидностью II группы, в домашних условиях - для лиц с инвалидностью I группы. Професссиональное обучение предлагалось небольщому количеству лиц с инвалидностью всех групп. Из услуг социальной реабилитации и технических средств реабилитации существенными были услуги социальных работников территориальных центров социального обслуживания для представителей всех групп, более простые средства для передвижения - для лиц с инвалидностью III группы и более сложные - для лиц с инвалидностью I группы. Определение особенностей потребностей военнослужащих с инвалидностью в зависимости от ее тяжести позволяет специалистам МСЭК более качественно формировать ИПР, разрабатывать целевые программы реабилитации на региональном уровне, оценивать недостатки в организации реабилитационного процесса и построении системы реабилитации участников боевых действий.

Ключевые слова: социальная защита, инвалидность, участники боевых действий, реабилитация. 